\title{
IMPLEMENTASI AIRLANGGA INTEGRATED REQUEST BOOK (AIRBOOK) SEBAGAI SARANA PENGEMBANGAN DAN PENGADAAN SUMBER INFORMASI (BUKU) DI PERPUSTAKAAN UNIVERSITAS AIRLANGGA
}

\author{
Farid AZ, Suhernik, Sugiati \\ Perpustakaan Universitas Airlangga \\ e-mail: farid@staf.unair.ac.id, suhernik97@yahoo.co.id
}

\begin{abstract}
ABSTRAK
Perkembangan teknologi menurut lembaga penyedia informasi harus sigap untuk memenuhi kebutuhan sumber informasi dengan cepat, tepat, dan mudah, tidak terkecuali perpustakaan. Dalam era teknologi informasi tersebut perpustakaan harus siap menghadapi tantangan kebutuhan sumber informasi pemustaka secara instan, termasuk dalam hal pengembangan dan pengadaan koleksi yang harus ada. Maka satu langkah lagi yang dilakukan oleh Perpustakaan Universitas Airlangga, di penghujung tahun 2019 membangun aplikasi AirBook. AirBook merupakan sebuah aplikasi berbasis web yang dapat digunakan oleh sivitas akademika UNAIR untuk mengusulkan permintaan (request) koleksi perpustakaan, yang dapat diakses melalui website perpustakaan www.lib.unair.ac.id/eproc.
\end{abstract}

Kata Kunci: Pengadaan Koleksi, Ailis, Perpustakaan

\section{PENDAHULUAN}

Perpustakaan Perguruan Tinggi adalah perpustakaan yang diselenggarakan oleh lembaga perguruan tinggi guna menunjang pelaksanaan program Tri Dharma Perguruan Tinggi, yang berarti tidak hanya diarahkan untuk membantu kegiatan pendidikan tetapi juga untuk penelitian dan pengabdian kepada masyarakat. Dengan demikian koleksinya harus relevan dengan kurikulum perguruan tinggi, program penelitian yang diterapkan, dan bentuk pengabdian kepada masyarakat yang telah digariskan oleh perguruan tinggi yang bersangkutan.

Perpustakaan merupakan salah satu komponen penting dalam setiap program pendidikan, pengajaran, dan penelitian (research) bagi setiap lembaga pendidikan dan ilmu pengetahuan. Dengan kata lain bahwa perpustakaan merupakan inti setiap program pendidikan dan pengajaran "The heart of the educational programs".

Fungsi Perpustakaan Universitas Airlangga sejalan dengan fungsi universitas. Perpustakaan berupaya berperan secara dinamis dan aktif, serta memberikan layanan yang maksimal bagi sivitas akademik UNAIR tanpa kecuali. Pada hakekatnya perpustakaan turut memperlancar dan menyukseskan visi dan misi universitas dalam mencapai World Class University.
Untuk mampu menjalankan fungsi-fungsi tersebut diatas, Neneng Komariah dalam Suhernik (2016; 37), ada beberapa persyaratan yang harus dipenuhi Perpustakaan Perguruan Tinggi, meliputi:

1. Mempunyai sumber informasi/koleksi yang baik;

2. Mempunyai staf yang kompeten;

3. Mengatur koleksi dengan baik, rapi dan teratur;

4. Mempunyai ruangan dan perlengkapan yang memadai untuk koleksi, staf perpustakaan dan pemakai;

5. Adanya integrasi perpustakaan dengan kebijaksanaan pendidikan dan administratif perpustakaan;

6. Adanya integrasi perpustakaan dengan sumbersumber perpustakaan secara nasional, internasional, regional dan masyarakat pendidikan sekitarnya;

7. Adanya dukungan dana yang memadai;

8. Adanya pengorganisasian dan perencanaan yang matang.

Sebagai sarana sumber belajar bagi SIVA Universitas Airlangga, perpustakaan senantiasa mengembangkan sumber informasi, baik dalam bentuk cetak dan non cetak, dalam pengembangan dan pengadaannya melibatkan SIVA. Beberapa cara yang dilakukan diantaranya: 
a. Menyeleksi koleksi melalui alat bantu seleksi yang tersedia, data buku dikirim ke fakultas untuk dipilih sesuai dengan kebutuhan sumber informasi di masingmasing fakultas

b. Menyediakan sarana online, yaitu tanda cinta yang bisa diakses melalui website perpustakaan www.lib. unair.ac.id. Tanda cinta merupakan salah satu sarana bagi SIVA untuk mengusulkan buku.

c. Menyediakan kertas ekspresi, melalui kertas tersebut SIVA bisa mengusulkan buku.

Namun cara-cara yang sudah dilakukan tersebut belum memberikan hasil yang maksimal, hanya beberapa SIVA yang memberikan usulan. Solusi yang dilakukan oleh perpustakaan adalah memilih bukubuku dari alat bantu seleksi, jenis buku yang diadakan adalah menyesuaikan dengan program studi yang ada di fakultas.

Berdasarkan kondisi diatas, maka perpustakaan membangun satu sistem untuk memberikan usulan pengadaan buku secara online yang bisa diakses melalui website perpustakaan www.lib.unair.ac.id/eproc

\section{KAJIAN PUSTAKA}

\section{Pengembangan dan Pengadaan Koleksi Perpustakaan}

Pengembangan koleksi meliputi kegiatan memilih dan mengadakan pustaka sesuai dengan kebijakan yang ditetapkan oleh pustakawan bersama-sama dengan sivitas akademika perguruan tingginya.

Perpustakaan diibaratkan sebagai jantungnya perguruan tinggi, karena tanpa perpustakaan proses pelaksanaan pembelajaran kurang optimal. Untuk mengoptimalkan proses pembelajaran, maka perpustakaan wajib membina koleksinya. Pembinaan koleksi harus direncanakan sebaik-baiknya agar layanan perpustakaan benar-benar memenuhi semua kebutuhaan para pemustaka. Oleh karena itu, untuk memenuhi semua kebutuhan pemustaka dibutuhkan pengadaan bahan pustaka yang terencana. Dengan demikian, diharapkan adanya kerja sama yang baik dan partisipasi dari pihak pemustaka baik dari mahasiswa, dosen, dan pimpinan dalam mengembangkan koleksi bahan perpustakaan.

Di perpustakaan perguruan tinggi, pengadaan bahan pustaka terletak pada pelayanan teknis. Hal ini disebabkan karena perpustakaan dapat memberikan informasi kepada pemustaka demi mencapai tujuan dari perpustakaan tersebut, yaitu mendukung, memperlancar dan meningkatkan kualitas pelaksanaan program Tri Dharma Perguruan Tinggi.

Dalam "Buku Pedoman Perpustakaan Perguruan Tinggi” (Dikti. 1994: 29), kebijakan pengembangan koleksi didasari asas berikut:

1. Kerelevanan

Koleksi hendaknya relevan dengan program pendidikan, pengajaran, penelitian dan pengabdian pada masyarakat perguruan tingginya. Karena itu, perpustakaan perlu memperhatikan jenis dan jenjang program yang ada. Jenis program berhubungan dengan jumlah dan besar fakultas, jurusan, program studi, lembaga dan seterusnya.

2. Beorientasi kepada kebutuhan pengguna

Pengembangan koleksi harus ditunjukkan kepada pemenuhan kebutuhan pengguna. Pengguna perpustakaan perguruan tinggi adalah tenaga pengajar, tenaga peneliti, tenaga administrasi, mahasiswa dan alumni yang kebutuhannya akan informasi berbedabeda.

3. Kelengkapan

Koleksi hendaknya jangan hanya terdiri atas buku ajar yang langsung dipakai dalam perkuliahan saja, tetapi juga meliputi bidang ilmu yang berkaitan erat dengan program yang ada secara lengkap.

4. Kemutakhiran

Koleksi hendaknya mencerminkan kemutakhiran. Ini berarti bahwa perpustakaan harus mengadakan dan memperbarui pustaka sesuai dengan perkembangan ilmu pengetahuan.

5. Kerja sama

Koleksi hendaknya merupakan hasil kerjasama semua pihak yang berkepentingan dalam pengembangan koleksi: yaitu antara pustakawan, tenaga pengajar, dan mahasiswa. Dengan kerjasama diharapkan pengembangan koleksi dapat berdaya guna dan berhasil guna. (Dikti. 1994: 29)

Pengembangan dan pengadaan koleksi Perpustakaan Universitas Airlangga berasal dari pembelian dan hadiah. Pembelian buku dilakukan melalui 2 cara, yaitu secara pembelian langsung dan lelang yang dilakukan koordinasi dengan unit Pusat Layanan Pengadaan (PLP) Universitas Airlangga. Sedangkan yang berasal dari hadiah, merupakan pemberian oleh penerbit, sivitas akademika Universitas Airlangga, lembaga/institusi perguruan tinggi/pemerintah, maupun alumni Universitas Airlangga.

Setiap tahun Perpustakaan Universitas Airlangga mendapatkan alokasi anggaran pengadaan koleksi, sumber 
dana BPPTN-BH. Dalam proses menyediakan koleksi bahan pustaka tersebut perpustakaan masih belum bisa maksimal. Permasalahan yang dihadapi yaitu terdapat rendahnya partisipasi SIVA dalam pemilihan koleksi yang harus dikembangkan dan diadakan di perpustakaan.

Upaya yang telah dilakukan oleh perpustakaan adalah menyebarkan daftar buku yang disesuaikan dengan disiplin ilmu bagi fakultas di lingkungan Universitas Airlangga, menyediakan kertas ekspresi, dan usulan tanda cinta secara online yang bisa diakses melalui website perpustakaan (www.lib.unair. ac.id). Namun upaya yang sudah dilakukan kurang mendukung perpustakaan menentukan kebijakan dalam pengembangan dan pengadaan koleksi, karena hanya sebagian kecil fakultas yang merespon data daftar buku yang dikirim perpustakaan.

\section{Metodologi}

Penulisan artikel ini menggunakan pendekatan studi kasus di Perpustakaan Universitas Airlangga, sehubungan dengan program pengadaan sumber informasi (buku) dalam rangka mencapai tingkat kesesuaian koleksi pustaka dengan kurikulum yang diterapkan di lingkungan universitas Airlangga

\section{PEMBAHASAN}

Kunci keberhasilan sebuah perpustakaan secara keseluruhan selain berada di pundak Sumber daya Manusia juga tergantung pada fasilitas dan koleksi yang dimilikinya, seperti pernyataan Soejono Trimo, bahwa:

"Sukses tidaknya pelayanan suatu perpustakaan itu tergantung pada tiga faktor yang hakekatnya dapat di prosentasikan sebagai berikut 5 $\%$ fasilitas dan kelengkapan gedung/ruang perpustakaan yang bersangkutan, $20 \%$ koleksi perpustakaan dan $75 \%$ adalah sebagai resultan dari staf perpustakaan yang bersangkutan". (Trimo, 1985)

Dalam pelaksanaan tugas dan fungsinya, Perpustakaan Universitas Airlangga mendukung pelaksanaan program Tri Dharma Perguruan Tinggi, sehingga perpustakaan wajib memberikan fasilitas bahan ajar bagi 15 (lima belas) fakultas yang terdiri dari 168 (seratus enam puluh delapan) program studi

Selama ini perpustakaan telah melalukan beberapa pendekatan ke fakultas dan program studi untuk memberikan dukungan dalam hal pengadaan buku. Namun sampai saat ini perpustakaan belum mampu menghitung tingkat kesesuaian koleksi pustaka dengan kurikulum yang diterapkan di lingkungan universitas Airlangga secara pasti. Padahal dalam pelaksanaannya perpustakaan harus mampu mengakomodasi dan memenuhi kebutuhan sumber informasi pemustaka.

Kehadiran teknologi informasi di perpustakaan tidak bisa lagi dihindari. Terkait dengan hal tersebut pustakawan utama dari Perpustakaan IPB, Abdul Rahman Saleh dalam Suhernik (Thesis;2006), menyatakan terdapat 6 (enam) alasan mengapa perpustakaan harus siap menerima kehadiran teknologi informasi tersebut dan harus diimplentasikan di perpustakaan, sebagai berikut:

1. Tuntutan terhadap jumlah dan mutu layanan perpustakaan

2. Tuntutan terhadap penggunaan koleksi bersama

3. Kebutuhan untuk mengefektifkan sumber daya manusia

4. Tuntutan terhadap efisiensi waktu

5. Keragaman informasi yang diterima

6. Kebutuhan akan ketepatan layanan informasi

Maka seiring dengan perkembangan teknologi informasi, Perpustakaan Universitas Airlangga membangun sistem berbasis web AirBook. Melalui aplikasi AirBook ini sivitas akademika Universitas Airlangga dapat mengusulkan koleksi yang dibutuhkan, sehingga koleksi yang ada mampu mengakomodasi kebutuhan buku bagi SIVA.

\section{AirBook}

AirBook merupakan sebuah aplikasi berbasis web yang dapat digunakan oleh sivitas akademika UNAIR untuk mengusulkan permintaan (request) koleksi perpustakaan, yang dapat diakses melalui website perpustakaan $w w w$.lib.unair.ac.id/eproc

Gagasan membangun aplikasi AirBook ini didasari Visi Perpustakaan Universitas Airlangga "Menjadi perpustakaan yang unggul dengan fasilitas yang lengkap, modern, dan mampu memberikan pelayanan terbaik kepada pemakai berbasis teknologi informasi dan komunikasi”.

\section{Fitur AirBook}

1. Menu Login

Sivitas akademika Universitas Airlangga memasukkan username dan password, untuk masuk ke aplikasi, dan selanjutnya SIVA bisa mengusulkan buku 


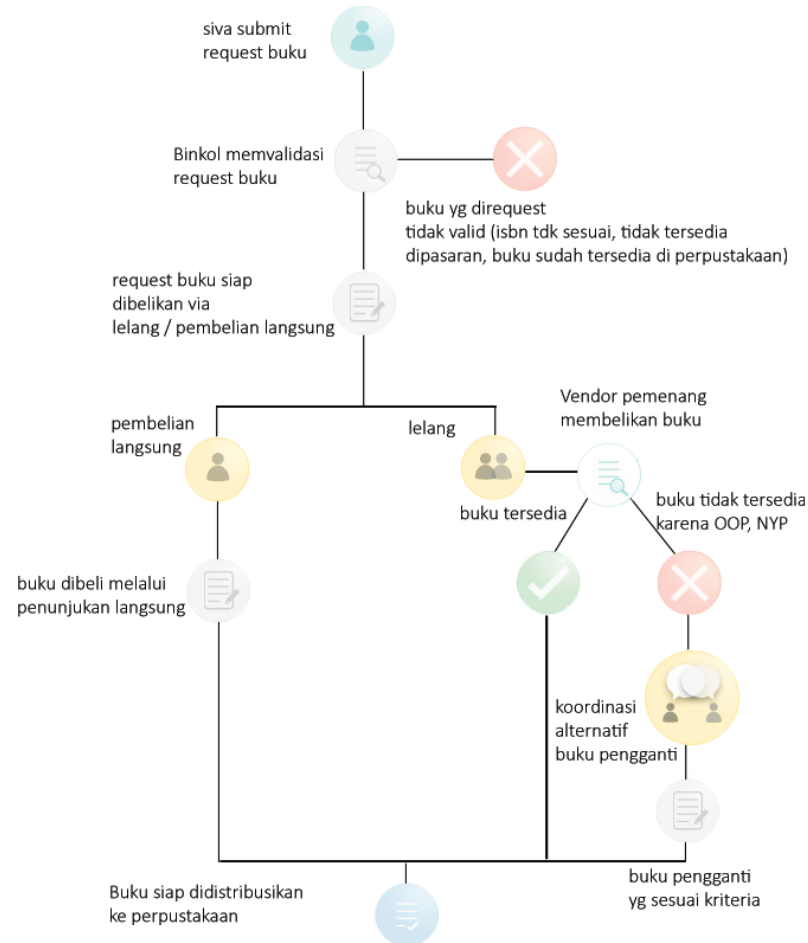

Gambar 1. Diagram Proses Informasi "AirBook"

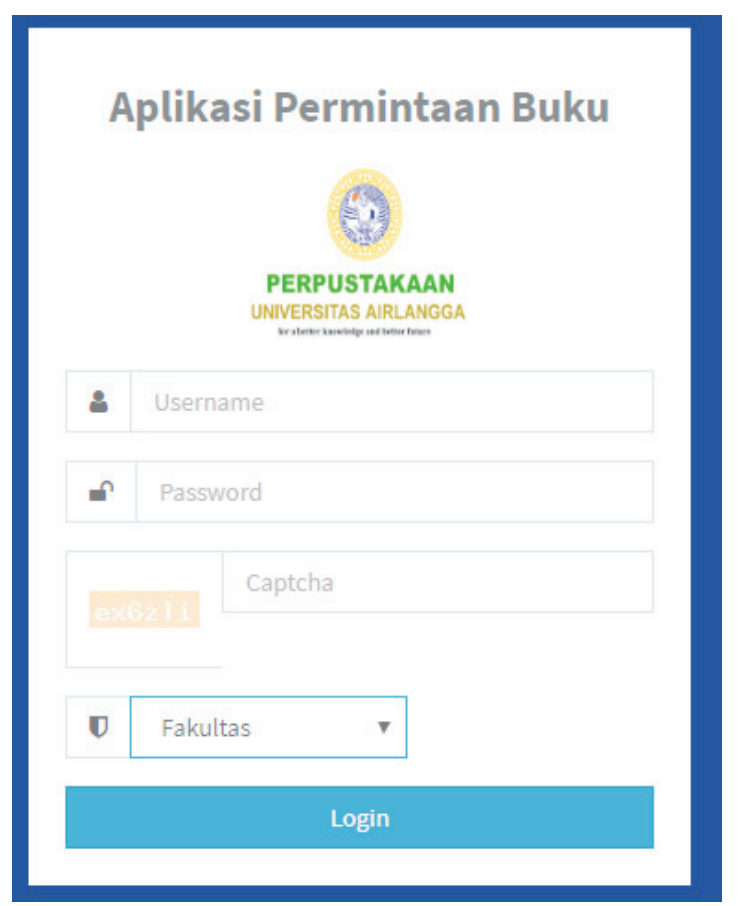

2. Menu Utama

Menu utama adalah halaman utama setelah login berhasil, tampilannya adalah sebagai berikut:

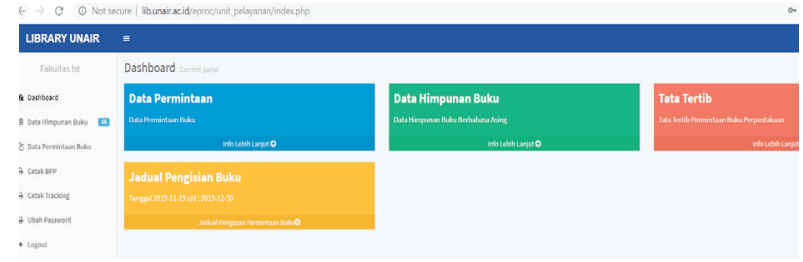

3. Menu Siva

Pengusul dapat memilih daftar buku yang sudah disediakan di aplikasi, dan bisa pula mengusulkan buku baru jika tidak ada pada daftar buku yang tersedia

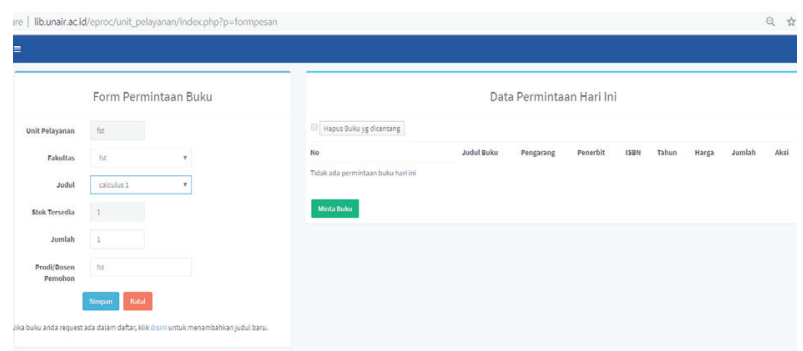

a. Menu Usulan Buku

Halaman daftar buku yang tersedia dan usulan buku baru

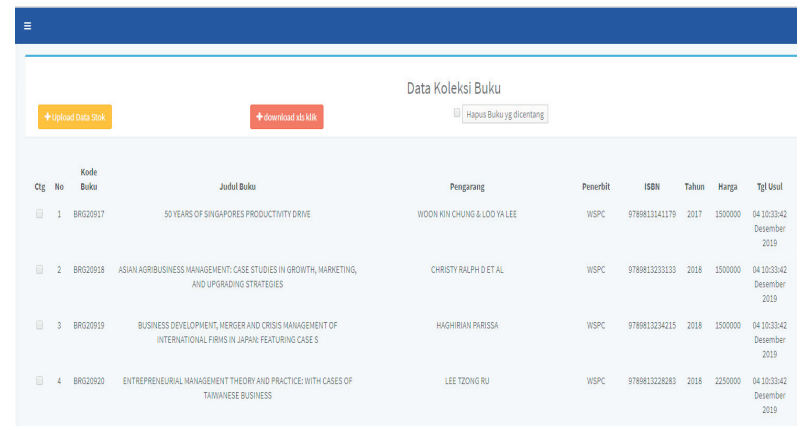

b. Menu Daftar Usulan Buku

Tampilan daftar buku usulan dari sivitas akademika Universitas Airlangga yang sudah divalidasi perpustakaan, dan siap untuk diusulkan ke Pusat Layanan Pengadaan Universitas Airlangga untuk proses lelang/pembelian langsung

4. Menu Perpustakaan

a. Menu Validasi Buku

Perpustakaan melakukan validasi buku yang diusulkan oleh sivitas akademika Universitas Airlangga 


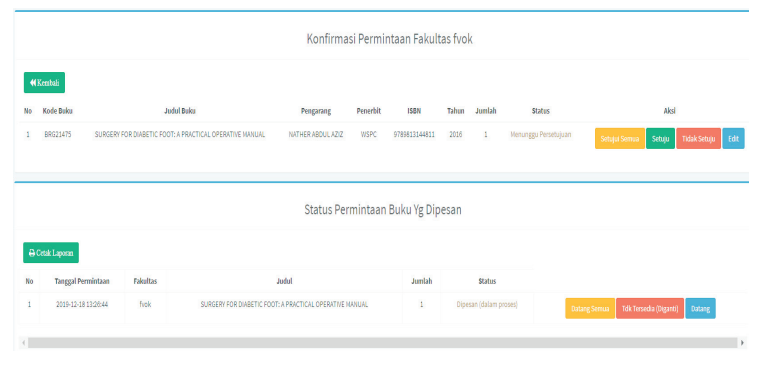

\section{Sosialiasasi AirBook}

Selain menginformasikan ke fakultas melalui surat yang ditujukan ke Dekan Fakultas di lingkungan UNAIR, perpustakaan telah melakukan kegiatan pengenalan AirBook kepada Pengelola Ruang Baca Fakultas dan tim Repository UNAIR, diantaranya:

- Pada tanggal 17 September 2019 perpustakaan telah melakukan sosialisasi kepada pengelola ruang baca fakultas, yang diselenggarakan di Ruang Parlinah Perpustakaan Universitas Airlangga.

- Pada tanggal 7 - 8 Desember 2019 perpustakaan mengadakan workshop bagi Pengelola Ruang Baca dan Tim Repository Universitas Airlangga, yang diselenggarakan di Hotel Savanah Malang.

\section{KESIMPULAN}

Perkembangan Teknologi informasi saat ini telah menjadi bagian dari kehidupan manusia seharihari. Kecanggihan yang didapatkan dari teknologi informasi memberikan kemudahan bagi pemustaka dalam mengakses berbagai informasi guna mendukung pelaksanaan program Tri Dharma Perguruan Tinggi.

Berbagai kecanggihan yang didapatkan pada teknologi informasi memberikan kesempatan bagi manusia mengasah otak dan pikiran untuk selalu berinovasi menciptakan hal-hal baru dan memberikan kebermanfaatan bagi setiap individu dan masyarakat yang kolerasinya terhadap kebutuhan informasi masa kini dan untuk masa yang akan datang. Untuk itu, maka perpustakaan mengembangkan inovasi layanan AirBook sebagai salah satu aplikasi berbasis web untuk menghimpun dan mengadakan koleksi atas usulan permintaan SIVA Universitas Airlangga, dihubungkan dengan website Perpustakaan Universitas Airlangga (www.lib.unair.ac.id/eproc).

\section{DAFTAR PUSTAKA}

Dirjen Pendidikan Tinggi. 1994. Buku Pedoman Perpustakaan Perguruan Tinggi. Jakarta: Dikti.

Komariah, Neneng. 2002. Pemanfaatan Alat Bantu Seleksi Bahan Pustaka Dalam kegiatan Pengembangan Koleksi Perpustakaan. FIKOM. UNPAD.

Suhernik.2006, Rancangan Program Dalam Meningkatkan Motivasi Dan Kemampuan Kerja PustakawanUpt. Perpustakaan Universitas Airlangga. Thesis. FIKOM. UNPAD.

Trimo, Soejono. 1985. Pedoman Pelaksanaan Perpustakaan. Bandung: Remadja Rosdakarya. 